\title{
ABOUT CHALLENGES OF THE MODERN WORLD: HEALTH, ENVIRONMENT AND SOCIAL DEVELOPMENT AMERICA LATINA CASE
}

\begin{abstract}
The XXI century brings social and environmental unquestionable imbalance; therefore, current world is becoming in an imminent challenge: to reach social and economic progress for upgrading all human beings quality of life and prosperity.

In this context, economic, social and environmental Latin America's evolution turns in a continuing instability so that results in important changes and transformations, strengthening its development and sustainability.

As for developing communicational and educational basic research was oriented; this was a descriptive and qualitative study based in multiples cases. Also, governmental data from Chilean Health Ministry, Colombian Health and Social Protection Ministry, General Health Promoter Management of Mexico and Bolivian Health and Sports Ministry was analyzed. Conclusions indicated agricultural industry, property, healthcare programs and cities advance according to governmental purpose (social and economic responsability) for energizing local and regional development, facilitating healthy, productive and sustainable systems and processes to the people.

Therefore, empowering the community about development like a social project oriented to the most vulnerable people, allowing interaction between economic, social and environmental factors, according with global context, becomes neccesary.
\end{abstract}

Key words: health, environment and development social

\section{Introduction}

The communication for Development concept recognizes that the protection of social, economic and environmental capitals are essential for achieving a productive development. In this sense, from the Communication and Development Project: a look at the Governmental Health Programs in Latin America. Cases: Bolivia, Chile, Colombia and Mexico some thoughts about the dynamics of development are provided to the general public to participate in a wellness facilitate its possibilities and options to your amp. In the same way,

Carlos Andrés Martínez Beleño, Msc, Universidad Autónoma del Caribe, Barranquilla, Colombia, e-mail: Carlosandres0513@hotmail.com 
it is necessary to recognize the communication as an important and necessary element in any development intervention, as it seeks to create spaces where individuals and their social environment can generate new imaginary scenarios.

From that perspective, communication management strategies for development, in order to get results in a healthy, productive, sustainable, sustainable society is a challenge that must be assumed from any individual, industry, community, either locally regional or national. In this connection, the Latin American case is difficult or almost unapproachable, having into account the dynamics presented in this region. The region is changes frequently and therefore management depending on how healthy, productive, sustainable and sustainable it is limited to meet the basic needs of the vulnerable population as they simply lack a model of urban planning but not only, social, political and economic transformation ever.

Nowadays, the phenomenon of globalization as a challenge, particularly for developing countries that in their eagerness to achieve development working for an independent business and cultural openness is studied. Under this, Gumucio (2001) emphasizes that communication processes, as more human version that is dialogue, or in their organizational and media projections, are a tool to support the transformations in which the man is the center. There is no economic, social or political development that does not have the middle man.

It is therefore conceivable that the irrefutable globalization model requires that each country, sector or economic system interested in participating plan and structure your needs, strengths and weaknesses, this translates to own and maintain a modern public management, a solid productive method, invest in science and technology innovation, formalization of work, education and training human talent to encourage and sustain the industrial and corporate processes and last being socially responsible.

Thus, Gonzalez, (2008) states that the many dimensions of the relationship with the environment are almost eclipsed by the dominant economic approach. This also shows that some perspectives emphasize the importance of not only working on the environment, "external", but also consider the relationship between people and the environment (related to "interior landscape").

\section{About challenges of the modern world for Latin America}

The economy of countries, companies and individuals are now conditioned by unchanging external forces, it is called globalization, which by its very nature leads to late opening competitiveness and economic growth.

To that extent, any system, structure or society want a development conducive to their own livelihood, ie interact cordially with environmental, cultural, social and economic not face each other, but conveniently coinciding and responding 
to the needs of context, which ultimately are the inclusion, equity, participation, quality education, access to services to meet unmet basic needs, among others. It looked that way, it is pertinent that as society, other actors from interfering in the sustainability of plans, projects and programs created to balance the above, otherwise is unthinkable achieve sustainability of not only economic, social, political, cultural or environmental but human.

Thus, Gonzalez, E. et al. (2008) states that the many dimensions of the relationship with the environment are almost eclipsed by the dominant economic approach. This also shows that some perspectives emphasize the importance of not only working on the environment, "external", but also consider the relationship between people and the environment (related to "interior landscape"). Others insist on the critical investigation of the root causes of the socio-ecological problems in the deconstruction of agendas "development" and the creative search for alternatives.

From this perspective, the environment has established itself as one of the most debated issues in political, economic and academics throughout the global sphere encounters, besides arousing the interest of private organizations, companies and associations that analyze the environmental risks inherent in the human.

In connection with the above, the environmental problems in Latin American developing countries come to be determined by the combination of three variables: the external, traditional and industrial development and capitalization. The environmental problems are both problems generated by the development and modernity and problems of backwardness and shortage.

The development of large Latin American cities from all dimensions is linked to the processes of industrialization (Gligo, 2001). For this it is necessary to mention that current cities have deep problems of planning, which leads us to show according to Sandia, (2009) when he says that the lack of comprehensive city planning makes the disorganization and chaos, as consequence of the social and economic dynamics, are in many respects the dominant axis in the development of it.

Consistent with the above, Vergara (2009) states that cities grow both a planned decision, planned and executed by an administrative political entity as the decision of its inhabitants, which makes the object of study of geography, ie, the space and the relationship established in him can not ignore the how, why and who uses the space and make it their territory of life. This ensures that even in a globalized world, where social, economic, political and cultural relationships occur at exponential rates, more rapid, more mediated, but at the same time, and that is the question, more specialized.

Consistently, the important thing is that the organization and planning of cities carried out thinking in terms of sustainability, to result in sustainable

Vol. 11, No 3, 2014: 135-144 
urban development, for any geographic space opportunities is in the ability to provide and expand or options of all inhabitants to the collective welfare.

In that measure, Santos (2000, p.67) cited by Vergara (2009) states that in the world of globalization, the geographic space gains new outline, new features, new definitions. And also new importance, because the effectiveness of actions is closely related to their location. The different social, environmental and economic dynamics and the need to move towards globalization lead to regional cities in particular trigger problems of Latin American urban land use planning, leading to the relocation of residential areas, deforestation and loss of reserves forest, indiscriminate expansion of avenues for commercial purposes pollution throughout their expressions and even leading to extreme poverty and inequality, all to make way for integrated systems development, which constantly affect the dynamics previously established either by political, economic or media by the inhabitants.

For Sanchez, (1984) Latin America has gone from an agrarian, rural society to an increasingly urban society, cities. This transition has been uneven across countries and within them. The Latin American city but has accompanied industrialization has accelerated over the past forming process. Its growth has been almost always extensive and impressive demographic concentration.

The already established cities alluding to the Colombian possess major problems of urbanization and planning, leading to a sudden, large green areas, districts, among other national treasures, are disappeared to make way for largescale political projects -economic as roads, tourist parks, resorts ie development, forgetting to turn on the sustainability of ecosystems and development with environmental or just healthy purposes, leading to chaos and traffic congestion, making Cities slow in mobility, in addition to an even more remote the possibility of achieving escape underdevelopment uncompetitive physical infrastructure, mainly roads and access to basic services. This characterizes the Colombian city. Either way there in Colombia specialized, modern or intelligent cities as the particular case of Medellin. Bogota Capital District even as this is far from.

As far as communication terms in health, environment and facilitate change processes, and is necessary manifest that is not presented to the media as the end to development, but as a medium employed as a strategy horizontally participatory and productive relevant in any area where you need your intervention. From that perspective, is preponderant think the close relationship between citizenship, participation, and development, as the first highly affects the second and both affect the latter.

A reason this, is necessary that at the level of nations and states, set the relationship between development and Growth and Economic, since from communication for development, with a focus on social change, the sustainability is the maximum level of development by which all individuals should move, 
which definitely should be paramount for Latin American, under which govern few sustainable models and therefore it will be difficult to achieve that level.

\section{Challenges as a health}

Table 1: Challenges as a health

\begin{tabular}{|l|l|l|}
\hline Strengths & Needs & Risks \\
\hline $\begin{array}{l}\text { 1. Proposals Governmental } \\
\text { Health: emphasis on }\end{array}$ & $\begin{array}{l}\text { 1. More and better coverage of } \\
\text { public health services. }\end{array}$ & $\begin{array}{l}\text { 1. Public Health Collective } \\
\text { 2. Prevention of diseases and } \\
\text { epidemics } \\
\text { Lifestyles }\end{array}$ \\
& $\begin{array}{l}\text { 2. Change consumer's habits and } \\
\text { unhealthy lifestyles } \\
\text { 3. Environmental, family and } \\
\text { local health }\end{array}$ \\
& 3. Strategies for Health \\
& Promotion and Health & \\
& Education & \\
\hline
\end{tabular}

\section{Challenges as to environment}

Table 2: Challenges as to environment

\begin{tabular}{|c|c|c|}
\hline Strengths & Needs & Risks \\
\hline $\begin{array}{l}\text { 1. Extensive agricultural } \\
\text { production }\end{array}$ & $\begin{array}{l}\text { 1. Ecological and healthy } \\
\text { production processes }\end{array}$ & $\begin{array}{l}\text { 1. Insertion to broad naturaland } \\
\text { international markets. } \\
\text { 2. Keep green measures according } \\
\text { to the current economic } \\
\text { demands. }\end{array}$ \\
\hline \multirow{2}{*}{$\begin{array}{l}\text { 1. FTAs } \\
\text { 2. Trade Agreements } \\
\text { 3. Active participation in } \\
\text { international negotiations } \\
\text { and multilateral regimes. }\end{array}$} & \multirow{2}{*}{$\begin{array}{l}\text { 1. The distribution and marketing } \\
\text { of processing technologies } \\
\text { and ever more efficient } \\
\text { distribution. Increase the } \\
\text { processes of sustainable } \\
\text { development. } \\
\text { 2. Educate depending on } \\
\text { the socio-environmental } \\
\text { sustainability s }\end{array}$} & $\begin{array}{l}\text { 1. Regional economic resources } \\
\text { (Need to spread progress in the } \\
\text { periphery.) }\end{array}$ \\
\hline & & $\begin{array}{l}\text { 2. The transition to a solid } \\
\text { economy and a competitive } \\
\text { and globalized commercial } \\
\text { production. } \\
\text { 3. Mobility and urban planning. } \\
\text { April. The environmental } \\
\text { health because of waste and } \\
\text { emissions from industry and } \\
\text { large-scale construction. }\end{array}$ \\
\hline
\end{tabular}




\section{Challenges as a social development}

Franco (2011) helps us to come up with five ways of understanding the process of social development. These forms are detailed as follows:

Table 3: Challenges as a social development

\begin{tabular}{|l|l|}
\hline Social Development as: & Definition: \\
\hline Involvement in Society: & $\begin{array}{l}\text { Process of advancement of a society that is approaching a desirable goal, } \\
\text { involves economic, social, political and cultural aspects. }\end{array}$ \\
\hline Human Welfare: & $\begin{array}{l}\text { Process that seeks to lift the standard of living and improved public access } \\
\text { to goods and services. }\end{array}$ \\
\hline Support Social Sectors: & $\begin{array}{l}\text { Improving the quality and coverage of quality basic social services such as } \\
\text { education, health and housing. }\end{array}$ \\
\hline Structural Change: & $\begin{array}{l}\text { The process by which inequalities between different social groups are } \\
\text { reduced. }\end{array}$ \\
\hline Social Support: & Improving the level of satisfaction of basic needs of the population. \\
\hline
\end{tabular}

This ultimately allows us to conclude that e 1 as the environmental component and Economic listed as means of ensuring the "future" of these cities as to the consolidation of a sustainable and productive development. To that extent, urban sustainability is conceived as a systemic concept, from which an alternative vision of the city originates, in this system, a settlement has the ability to provide durable and efficient resources that would help offset the inequality depending on the social context. (Lopez, 2008)

\section{Conclusions}

It is a must for Latin America, as a region in constant transformation, achieve socio-economic and environmental development in cities achieve a process healthy, productive, sustainable, sustainable, where prime fairness and respect, where these prevail suitable for healthy and free development, where human presence is socially just and environmentally sustainable. The sustainable city is, ultimately, a challenge of the current generation and passes through a comprehensive understanding of the city as a living, special and exclusive system that is built every day with planned, participatory and concerted action of its inhabitants.

In this vein, the important thing is that the organization and planning of cities carried out thinking in terms of sustainability, to result in sustainable urban development, for any geographic area is in the ability to provide and expand opportunities or options for all residents. 
From that perspective, Sandia, (2009) states that in the case of Latin America, the pursuit of sustainability must also be one of the challenges to be achieved in the coming decades, in order to guarantee all its inhabitants cities for healthy life , decent work and healthy enjoyment, where the individual and the community can achieve increasing levels of development and prosperity. This ultimately would overcome the almost dominant contemporary city, largely overwhelmed by the urban chaos, pollution, crime, violence, and where most, especially the poorest, suffering city rather than live it and enjoy it. (Sandia, 2009).

Looked like a sustainable society with a view to sustainability, should purify itself of pollution, acquire new skills, make your more efficient and sustained production processes, improve their own management, distribute resources equitably and be diversified. (Lopez, 2008). For these reasons, it is inevitable that mobilize society towards sustainability, otherwise social, economic, political, productive and environmental conditions will be pejorative.

Thus, the relationship between the productive and sustainable, viable long survive as the dominant economic model is ductile as facilitate the provision of resources according to the environmental, health and invest in technology, education towards sustainability and not only for life but in life, as the immediate future requires decisive action today in terms of maintaining a satisfactory development, intending to enjoy an environment and a horizontal economically and socially productive.

\section{Literature}

- Aragonés, J., Amérigo M. (2002). Psicología Ambiental. Ediciones. Pirámide.

- Cárdenas M. (1986) ed. Política Ambiental y Desarrollo. Un debate para América Latina. FESCOL - INDERENA. Colombia.

- González, E. (2008). Educación, Medio Ambiente y Sustentabilidad. Siglo XXI editores: Universidad Autónoma de Nuevo León. México

- Franco R. (2001). Significado y contenido del desarrollo social y de las políticas sociales. Índice de Desarrollo Social. Costa Rica APSAL. ISUC. Tomado de MIDEPLAN.

- Gligo, N. (2001). La dimensión ambiental de desarrollo de América latina. Santiago de Chile: Cepal - Naciones Unidas.

- López, O. (2008). La sustentabilidad urbana: una aproximación a la gestión

- ambiental en la ciudad. Cali-Colombia: Programa Editorial Universidad del Valle 
- Martínez, C. (2011). El Agente Comunitario y la Vivienda Saludable como componentes para la Calidad de Vida y el Desarrollo Auto-sostenible. InFÁRMAte, 7(26):pp. 232-237.

- Martínez, C. (2011). Vivienda y Entornos Saludables para el Desarrollo Humano Sostenible. En Memorias del I Congreso Internacional y del Caribe en Salud Ambiental y Ocupacional. Disponible en:

- http://www.uninorte.edu.co/I_congreso_int_Salud_Ambiental_Ocupacional/ upload/File/4a-martinez-colombia-01.pdf

- Sánchez, R. (1984). Estado y Planeación en Colombia. Bogotá, editorial la Rosa Roja.

- Sandia, L. (2009). El ambiente y el desarrollo sustentable en la ciudad latinoamericana. Investigación y Desarrollo, 17, pp. 268-287.

- Sunkel, O. (2000). La sostenibilidad del desarrollo vigente en América latina. Historia Crítica. pp. 20, 8-54.

- Vergara, A. (2009). La mirada de la geografía en un continente en transformación: problemáticas urbano-regionales del desarrollo. Investigación y Desarrollo. 17, pp. 230-241.

Paper received: May $15^{\text {th }}, 2014$

Approved for publication: June $1^{\text {st }}, 2014$
Rad primljen: 15. maj 2014. Odobren za štampu: 1. jun 2014. 
Ms Carlos Andrés Martínez Beleño,

Univerzitet „Autonoma del Caribe“, Kolumbija

\section{IZAZOVI MODERNOG SVETA: \\ ZDRAVLJE, ŽIVOTNA SREDINA I DRUŠTVENI RAZVOJ SLUČAJ LATINSKE AMERIKE}

\section{S a ž e t a k}

XXI vek donosi neuravnoteženost u društvu i životnoj sredini. Stoga, sadašnji svet postaje izazov: dostignuti društveni i ekonomski napredak koji će unaprediti živote i dobrobit svih ljudsjih bića.

U tom smislu, evolucija u ekonomskom, društvenom i latinoameričkom stanju životne sredine je u večitoj nestabilnosti, koja uzrokuje važne promene i transformacije, ojačavajući njihov razvoj i održivost.

Ukazala se potreba za razvijanjem komunikacionog i obrazovnog istraživanja na ovu temu: ovo je opisna i kvalitativna studija zasnovana na više slučajeva. Takođe, korišćeni su i analizirani državni podaci čileanskog ministarstva zdravlja, kolumbijskog ministarstva zdravlja i društvene zaštite, meksičkog promotera opšteg zdravlja i bolivijskog ministarstva zdravlja i sporta. Zaključci ukazuju na poljoprivredu, imovinu, programe zdravstene zaštite i gradove koji napreduju u zavisnosti od državne namene (društvene i ekonomske odgovornosti), radi podsticaja lokalnog i regionalnog razvoja, omogućavajući zdrave, produktivne i održive sisteme i procese u društvu.

Stoga se pokazalo kao potrebno da se omogući zajednici da razvija društvene projekte koja se tiču najugroženijih slojeva stanovništva i da se dozvoli interakcija, u globalnom smislu, između ekonomskih i društvenih faktora, kao i faktora životne sredine.

Ključne reči: zdravlje, životna sredina, društveni razvoj 
